ORIGINAL ARTICLE

\title{
Genetic progress in the breeding population of Zeyheria tuberculosa (Ipê-felpudo): from theoretical predictions to clonal recombination orchard assembly
}

\author{
Progresso genético em população de melhoramento de Zeyheria \\ tuberculosa (Ipê-felpudo): de predições teóricas à formação de pomar de \\ recombinação clonal.
}

\author{
Marlon dos Santos Pereira Birindiba Garuzzo ${ }^{1}$ (D) Andrei Caíque Pires Nunes ${ }^{1}$ (D), \\ Aline Pinto dos Santos ${ }^{2}$ (D), Felipe Garbelini Marques ${ }^{3}$ (D) \\ ${ }^{1}$ Universidade Federal do Sul da Bahia - UFSB, Itabuna, BA, Brasil \\ ${ }^{2}$ Universidade Estadual de Santa Cruz - UESC, Ilhéus, BA, Brasil \\ ${ }^{3}$ Symbiosis Investimentos e Participações S. A., Trancoso, BA, Brasil
}

How to cite: Garuzzo, M. S. P. B., Nunes, A. C. P., Santos, A. P., \& Marques, F. G. (2021). Genetic progress in the breeding population of Zeyheria tuberculosa (Ipê-felpudo): from theoretical predictions to clonal recombination orchard assembly. Scientia Forestalis, 49(131), e3653. https://doi.org/10.18671/scifor.v49n131.18

\begin{abstract}
Zeyheria tuberculosa (Ipê-felpudo) is a promising timber species with high silvicultural potential, but genetic breeding of this species is incipient. In order to promote genetic breeding programs of Z. tuberculosa, this study aimed to: (a) characterize the genetic variability of the species via a progenies and provenances test; (b) select mother trees, potential parents, and potential clones; (c) evaluate genetic progression of future breeding populations; and (d) study the viability of the grafting process for the establishment of a clonal recombination orchard. The experiment consisted of a progeny and provenance test of $Z$. tuberculosa in the municipality of Porto Seguro, Southern Bahia State, Brazil. The test was composed of 30 open pollination families in a randomized block design with 10 blocks of singletree plots in $4 \mathrm{~m} \times 4 \mathrm{~m}$ grids. The traits evaluated at 3.5 years of age were diameter at breast height $(\mathrm{DBH})$ and stem quality. The $Z$. tuberculosa population of the test presented moderate genetic variability for DBH (individual heritability 0.26 ). Predicted genetic gains with selection of mother trees, potential parents and clones ranged from $6.29 \%$ to $75.99 \%$, indicating success with selection. The simulation of open pollination between the ten best potential parents for DBH and stem shape estimated the genetic progress of the future population as being $20.51 \%$. The ten best potential parent trees were cloned using a grafting technique in order to assemble a clonal controlled pollination orchard. The mean success rate of grafting was $51 \%$, ranging from $20 \%$ to $80 \%$ according to genotype. Overall, our results demonstrated that genetic breeding of $Z$. tuberculosa should be considered, since genetic progress for stem growth is possible and clonal recombination orchards can be set up using grafting techniques.
\end{abstract}

Keywords: Progeny and provenance test; Half-sib families; Forest breeding; Timber species.

\section{Resumo}

Zeyheria tuberculosa (Ipê-felpudo) é uma espécie florestal promissora com alto potencial silvicultural, mas o melhoramento genético dessa espécie está em fase inicial. Com o objetivo de impulsionar programas de melhoramento genético de $Z$. tuberculosa, este estudo teve como objetivos: (a) caracterizar a variabilidade genética da espécie por meio de um teste de progênies e procedências; (b) selecionar matrizes, potenciais genitores e potenciais clones; (c) avaliar o progresso genético de futuras populações

Financial support: Conselho Nacional de Desenvolvimento Científico e Tecnológico, Nº do processo: 433173/2018-1.

Conflict of interest: Nothing to declare.

Correspondig author: marlongaruzzo@gmail.com

Received: 21 December 2020.

Accepted: 18 February 2021.

Editor: Paulo Henrique Müller Silva.

(c) This is an Open Access article distributed under the terms of the Creative Commons Attribution License, which permits unrestricted use, distribution, and reproduction in any medium, provided the original work is properly cited. 
de melhoramento; e (d) estudar a viabilidade do processo de enxertia para formação de um pomar de recombinação clonal. O experimento consistiu em um teste de progênies e procedências de Z. tuberculosa no município de Porto Seguro, Sul da Bahia, Brasil. O teste foi composto por 30 famílias de polinização aberta em um delineamento de blocos casualizados com 10 blocos em parcelas de árvore única em espaçamento de $4 \mathrm{~m} \times 4 \mathrm{~m}$. As características avaliadas aos 3,5 anos de idade foram diâmetro à altura do peito (DAP) e qualidade do fuste. A população do teste apresentou moderada variabilidade genética para DAP (herdabilidade individual igual a 0,26 ). Os ganhos genéticos preditos com a seleção de matrizes, potenciais genitores e potenciais clones variaram de 6,29\% a 75,99\%, indicando sucesso com a seleção. A partir da simulação de polinização aberta entre os dez melhores potenciais genitores para DAP e forma do fuste, o progresso genético da população futura foi estimado em $20,51 \%$. Os dez melhores potenciais genitores foram clonados por meio da técnica de enxertia para montagem de pomar clonal de polinização controlada. A taxa média de sucesso da enxertia foi de $51 \%$, variando de $20 \%$ a $80 \%$ de acordo com o genótipo. Dessa maneira, o melhoramento genético de $Z$. tuberculosa deve ser considerado, uma vez que o progresso genético para o crescimento do fuste é possível e pomares de recombinação clonal podem ser elaborados usando a técnica de enxertia.

Palavras-chave: Testes de progênies e procedências; Famílias de meios-irmãos; Melhoramento florestal; Espécie madeireira.

\section{INTRODUCTION}

Brazil has the highest biodiversity of trees in the world; there are 8,715 native tree species in the country, of which 4,333 are endemic (Beech et al., 2017). This range of genetic material has the potential to be used in diverse ways for the benefit of society and to complement traditional forest plantations, which are currently mostly monocultures of non-native species (Food and Agriculture Organization of the United Nations, 2020). In order to make native Brazilian species more common in plantations worldwide and, thus, complement the supply of wood products, techniques for forest tree breeding must be adopted, as these allow for the use of superior individuals in plantations.

In tropical regions, the supply of wood from native Brazilian species has diminished in the past few decades, although the demand has continued to grow (Tian et al., 2016). As a result, research on genetic breeding of native Brazilian tree species has developed in the last few years. However, a lack of investment has led to research being discontinued, and few concrete results have originated from these studies. Nevertheless, it is known that timber species like Zeyheria tuberculosa (Vell.) Bureau ex Verl have a high silvicultural potential, and efforts have been made to proceed with the genetic breeding of this species. Thus, in order to guarantee the initial progress of $Z$. tuberculosa breeding populations, efforts should be focused on the selection of families and individuals with high genetic value, and individuals with high genotypic values should subsequently be cultivated as clones (Carvalho et al., 2019).

The genetic breeding process begins with the selection of trees evaluated in progeny/provenance tests. In this step, components of variance and genetic parameters are analyzed in order to discover the genetic control of the traits and to predict the genetic value of progenies (Gallo et al., 2018). From genetic parameter analysis and genetic value prediction it is possible to evaluate the gene action involved in inheritance and to classify trees based on their genetic value, with the best genotypes being directed to artificial crossing schemes (Dickinson et al., 2010). In this way, elite genotypes, with appropriate phenotypes related to traits of commercial interest, are generated.

The breeding of tropical timber species requires many cycles of selection and recombination in order to increase genetic gains through the selection of superior progenies (Mendes et al., 2020). Grafting techniques combined with the application of growth regulators are often used to accelerate this selection process, as they can induce early flowering of superior genotypes ranked for crossing schemes. With such procedures, plants arranged in pots, i.e., plants that are reduced in size and height of the crown, can quickly reach the flowering stage, thus facilitating processes such as plant management, artificial fertilization of flowers, and harvesting of seeds in indoor hybridization orchards (Mendes et al., 2020). Consequently, crossed individuals can be used for experimental plantings such as for ecological restoration projects or commercial industrial plantations. 
There are few studies aimed at examining the best use of $Z$. tuberculosa wood. Some studies have been conducted to evaluate its performance in agroforestry systems. Nicodemo et al. (2016), investigated the antimicrobial effects of its extract (Sarmento et al., 2014), and describe its silvicultural traits and morphological properties (Mendonça et al., 2017). Some native Brazilian species-such as Myracrodun urundeuva (Freitas et al., 2006, 2007), Ilex paraguariensis (Costa et al., 2005), Cariniana legalis (Sebbenn et al., 2002, 2009), and Araucaria angustifolia (Gianotti et al., 1982; Duarte et al., 2012)-are already in the process of genetic breeding, with programs in place to assess genetic parameters and test provenances and progenies. Despite this, studies that explore beyond the testing of progenies in the field and advance the genetic breeding of Brazilian native timber species to the stages of grafting, induction of early flowering, and controlled pollination of selected materials, are scarce.

Considering these aspects, the present study aimed to (a) characterize the genetic variability of Z. tuberculosa progeny and provenance test; (b) select mother trees, potential parent trees, and potential clones through statistical genetic analysis; (c) evaluate future genetic progress of the breeding population; and (d) study the grafting viability of selected individuals for the assembly of clonal recombination orchards.

\section{MATERIALS AND METHODS}

\section{Genetic material and experimental design}

The experimental site, where a progeny and provenance test of $Z$. tuberculosa was conducted, was located on the Symbiosis Investimentos e Participações S. A. property in the

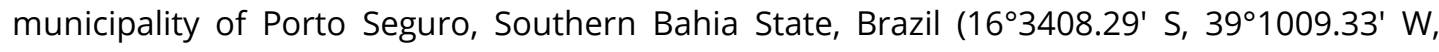
elevation $56 \mathrm{~m}$ ). The mean temperature of the area is approximately $25^{\circ} \mathrm{C}$, with higher temperatures occurring from December to March and lower temperatures from June to September. The annual precipitation is approximately $1,500 \mathrm{~mm}$.

First, the seed donor trees were screened in the natural rainforests of southeastern Brazil, in 12 municipalities of the states Rio de Janeiro, Minas Gerais, and Espírito Santo. The circumferences at breast height, commercial height and shape of each seed donor tree (mother trees) were measured. Subsequently, the seed donor trees were phenotypically selected, and the seeds were collected to conduct a progeny and provenance test. The test was established in November 2013, using 30 seed donor trees. The statistical arrangement used was a randomized block design of 10 blocks with single-tree plots in a $4 \mathrm{~m} \times 4 \mathrm{~m}$ grid.

\section{Trait measurements}

The trees were evaluated at 42 months (3.5 years) of age. All individuals were evaluated for the following traits: circumference at breast height $(\mathrm{CBH}, \mathrm{cm})$, number of stems, survival (\%), tree shape, and branch thickness. The trait CBH was determined with the aid of a measuring tape; the other traits were determined via observations. Regarding tree shape, trees with straight stems were assigned Grade 1, those with a soft tortuosity were assigned Grade 2, those with a medium tortuosity were assigned Grade 3, and those with a loss of apical dominance were assigned Grade 4. For branch thickness, Grades 1, 2, and 3 corresponded to thin, medium, and thick branches, respectively. The $\mathrm{CBH}$ values were converted to diameter at breast height (DBH).

\section{Quantitative genetic analysis and selection of superior genotypes}

In order to estimate the genetic parameters of the studied traits and predict genetic and genotypic values of individuals and families, a model given by the equation $\mathrm{y}=\mathrm{Xr}+\mathrm{Za}+\mathrm{Ts}+$ e was used, where: $y$ is the data vector, $r$ is the vector of block effects (assumed to be fixed) plus the overall mean, $a$ is the vector of individual genetic effects (assumed to be random), $s$ is the vector of provenance effects (random), and e is the vector of errors or residuals (random). The incidence matrices of these effects are represented by capital letters. All data 
were analyzed using the mixed model methodology and the Restricted Maximum Likelihood/Best Linear Unbiased Predictor (REML/BLUP) method in the Selegen REML/BLUP software (Resende, 2016).

Subsequently, individuals belonging to families with positive genetic effects were selected according to their genetic values, genotypic values, and their superior stem shape (Grade 1, i.e., straight stem). For future crosses among the best genotypes, only one best-ranked individual was selected as a potential parent tree (selection based on the genetic value) from each of the top 10 families. These top 10 best-ranked potential parent trees will be the target of our future studies on early flowering and controlled pollination.

\section{Family selection}

Families were ranked based on the genetic value $(u+a)$ for the silvicultural trait diameter at breast height (DBH). The 10 best families were selected. The selection gain for each family was given by the following Equation 1:

$$
\operatorname{Gain}(\%)=\frac{\left(\left(u+a_{f s}\right)-\bar{X}_{g}\right)}{\bar{X}_{g}} \times 100
$$

Where, $\left(u+a_{f s}\right)=$ Genetic value of the selected family; $\bar{X}_{g}=$ Overall mean of the experiment.

\section{Selection of potential progenitors}

After analyzing the traits using the Selegen REML/BLUP software, we obtained the ranking of potential progenitors by their genetic values $(u+a)$. From this order, selection was made considering the following criteria: individuals evaluated in Grade 1 for stem shape (straight stem) and positive genetic gain in relation to the general population mean for the trait $\mathrm{DBH}$; and individuals who belonged to families with positive genetic effect. One individual was selected from each of the top 10 families. The predicted gain was calculated using the following Equation 2:

$$
\operatorname{Gain}(\%)=\frac{\left(\left(u+a_{i s}\right)-\bar{X}_{g}\right)}{\bar{X}_{g}} \times 100
$$

Where, $\left(u+a_{i s}\right)=$ Genetic value of the selected individual; $\bar{X}_{g}=$ Overall mean of the test.

\section{Selection of potential clones}

The selection of potential clones was carried out using the genotypic value $(u+g)$ of each individual, and the ranking was done according to the estimation of the selection gain for the DBH trait in relation to the general population mean. The calculated gain of the potential clones was given by the Equation 3:

$$
\operatorname{Gain}(\%)=\frac{\left(\left(u+g_{i s}\right)-\bar{X}_{g}\right)}{\bar{X}_{g}} \times 100
$$

Where, $\left(u+g_{i s}\right)=$ Genotypic value of each potential clone; $\bar{X}_{g}=$ General mean of the experiment. 


\section{Genetic progress}

With the ranking of potential progenitors, an analysis of the genetic progress of the $Z$. tuberculosa breeding population was carried out. For this, an open cross scheme was simulated involving the best potential parent trees selected from the 10 best families. Genetic gains with selection were predicted for the seeds of the new future population. The estimated DBH mean (E.D.M.) of future plants from the seeds of each of the selected trees was calculated by the sum of half the genetic value of the potential progenitor plus half the genetic value of the population mean of selected individuals, using the following Equation 4:

E.D.M. $=\frac{1}{2}\left(u+a_{i s}\right)+\frac{1}{2}\left(\bar{X}_{s}\right)$

Where, E.D.M = Estimated DBH mean of trees from the seeds collected in each selected tree; $\left(u+a_{i s}\right)=$ Genetic value of the selected individual; $\left(\bar{X}_{s}\right)=$ Genetic mean of individuals selected for the cross simulation.

The genetic gain for each E.D.M. was calculated according to Equation 5:

$\operatorname{Gain}(\%)=\frac{\left(E \cdot D \cdot M \cdot-\bar{X}_{g}\right)}{\bar{X}_{g}} \times 100$

Where, E.D.M. = Estimated DBH mean of trees from the seeds collected in each selected tree; $\bar{X}_{g}=$ General mean of individuals in the original population.

Moreover, the genetic progression of the Z. tuberculosa population was carried out, which was illustrated in a graph built using the R software (R Development Core Team, 2020). For this, the mean displacement (delta) of the breeding population from the open cross simulation among the selected individuals was considered in relation to the overall mean of the original population.

The genetic gain or overall mean displacement of the breeding population was calculated using the following Equation 6:

Meanoffset $=\bar{X}_{E \cdot D \cdot M}-\bar{X}_{g}$

Where, Mean offset $=$ overall mean displacement or mean genetic progress; $\bar{X}_{E . D . M .}=\mathrm{DBH}(\mathrm{cm})$ mean of trees originated from seeds collected in the top ranked individuals used in the genetic progress simulation; $\bar{X}_{g}=$ Overall mean of the experiment relative to the original breeding population.

\section{Grafting}

In order to make the compatibility between the graft and the rootstock feasible, 10 seedlings of seed origin were produced from each of the superior $Z$. tuberculosa mother trees. The seedlings were grown in polyethylene pots with a capacity of $5 \mathrm{~L}$, fertilized with $40 \mathrm{~g}$ of slow-release fertilizer, and handled until they reached the ideal size for grafting (Mendes et al., 2020). These seedlings were used as rootstock in order to increase the grafting success rates, since they presented $25 \%$ compatibility with the graft.

The graft was obtained from the median portion of the canopy of the mother trees, which were in healthy conditions and with many fruits. Grafts with a thickness of approximately 4 $\mathrm{cm}$ and a size of $12 \mathrm{~cm}$ were chosen, being collected from the 10 individuals selected after genetic analysis to identify the 10 best mother trees. The grafting procedure was carried out at the Laboratório de Heveicultura da Comissão Executiva do Plano da Lavoura Cacaueira in 
the municipality of Ilhéus, BA. The top wedge grafting technique was used (Mendes et al., 2020).

After the grafting, the seedlings were kept in the nursery and watered constantly, avoiding wetting the graft union region due to the likelihood of attack by harmful agents (such as insect pests, bacteria, and fungi) that can benefit from the excess humidity in the region of cutting. Therefore, 100 grafts were made, corresponding to 10 rescued individuals, replicated 10 times. The graft taking assessment was performed after 60 days of grafting, and the rate of total fixation by genotype was verified.

The diameter measurements of rootstocks and grafts were performed on the day of grafting with digital calipers. A statistical analysis of the correlation between trait relatedness of grafts and rootstocks, mean diameter of the rootstocks, mean diameter of the grafts, and grafting success rate was performed using the Rbio software (Bhering, 2017).

\section{RESULTS AND DISCUSSION}

\section{Genetics Parameters}

The genetic parameter analysis provided estimates for the silvicultural traits $\mathrm{DBH}$, number of stems, survival (\%), tree shape, and branch thickness (Table 1). These estimates are essential to assess the availability of genetic variation in a breeding population and to establish breeding strategies. The evaluated $Z$. tuberculosa population had a genetic variability in relation to the DBH trait, making it possible to obtain genetic gains in new generations of breeding. The individual heritability $\left(h_{a}^{2}\right)$ revealed that DBH was the most appropriate trait for selection. In addition, there was a low variation between provenances $\left(c_{\text {proc }}^{2}\right)$ for all traits. Thus, it can be concluded that there is no provenance effect and selection must be performed between and within families.

Table 1. Estimates of genetic parameters for diameter at breast height $(\mathrm{DBH}, \mathrm{cm})$, number of stems, tree shape, branch thickness and survival (\%) for the progeny and provenance test of $Z$. tuberculosa half-sib families.

\begin{tabular}{cccccc}
\hline & DBH & N.S. & T.S. & B.T. & Survival \\
\hline$h_{a}^{2}$ & 0.26 & 0.01 & 0.11 & 0.24 & $\sim 0.00$ \\
$c_{p r o c}^{2}$ & 0.05 & 0.01 & 0.01 & 0.02 & 0.03 \\
$C V_{g i} \%$ & 19.99 & 3.29 & 17.36 & 18.04 & 3.65 \\
$C V_{p g} \%$ & 10.00 & 1.65 & 8.68 & 9.02 & 1.82 \\
$C V_{e} \%$ & 2.14 & 1.99 & 2.96 & 2.04 & 3.18 \\
$C V_{r}$ & 4.67 & 0.83 & 2.94 & 4.41 & 0.57 \\
$r_{a ̂ a}$ & 0.54 & 0.12 & 0.39 & 0.53 & 0.08 \\
General mean & 7.84 & 1.14 & 2.25 & 1.92 & 0.74 \\
\hline
\end{tabular}

N.S.: Number of stems; T.S.: Tree shape; B.T.: Branch thickness; $h_{a}^{2}$ : individual heritability in the strict sense; $c_{\text {proc }}^{2}$ : coefficient of determination for provenances effects; $C V_{g i} \%$ : individual genetic variation coefficient; $C V_{p g} \%$ : coefficient of genotypic variation between progenies; $C V_{e} \%$ : residual variation coefficient; $C V_{r}$ : Coefficient of relative variation; $r_{\hat{a} a}$ : Accuracy of the experiment.

When evaluating the survival trait for the $h_{a}^{2}$ parameter, a null value was obtained, indicating low genetic control. Thus, the dead trees in the tests were caused by the handling of the experiment, environmental or random effects and were not a result of genetic control. The values obtained for the number of stems (0.01) and tree shape (0.11) were of a low magnitude, and those for DBH (0.26) and branch thickness (0.24) were moderate. Similar results were found for the native Brazilian species Myracrodruon urundeuva (0.27) (Guerra et al., 2009), Peltophorum dubium (0.25) (Senna et al., 2012), Dipteryx alata (0.27) (Zaruma et al., 2015), Terminalia argentea (0.27), Astronium fraxinifolium (0.20) (Otsubo et al., 2015), Balfourodendron riedelianum (0.15) 
(Kubota et al., 2015), and Plathymenia reticulata (0.20) (Mendes, 2019). For tree shape, similar values as that of Z. tuberculosa in our study were observed in Dipteryx alata (0.11) (Zaruma et al., 2015), Myracrodruon urundeuva (0.14) (Guerra et al., 2009), and Balfourodendron riedelianum (0.12) (Kubota et al., 2015). These estimates reveal that the population presents variability for genetic breeding in relation to $\mathrm{DBH}$, tree shape, and branch thickness, enabling genetic gains to be obtained with future evaluations and selections.

The population effect variation coefficient $\left(c_{\text {proc }}^{2}\right)$ presented values that varied from 0.01 for number of stems and tree shape to 0.05 for DBH. Compared with heritability, these magnitudes are low for all traits, indicating low variation among the provenances. In terms of the coefficient of individual genetic variation ( $\mathrm{CV}_{g i} \%$ ), high values were observed in relation to the residual variation $\left(\mathrm{CV}_{e} \%\right)$ for the traits $\mathrm{DBH}$ (19.99), tree shape (17.36) and branch thickness (18.04). Similar results for $\mathrm{CV}_{g i} \%$, in relation to DBH were found for Peltophorum dubium (20.30) (Sebbenn et al., 1999), Dipteryx alata (17.1) (Zaruma et al., 2015), and Myracrodruon urundeuva (18.82-16.0) (Moraes et al., 2012; Canuto et al., 2017). Accuracy $\left(r_{\hat{a} a}\right)$ varied from 0.08 for survival to 0.54 for DBH. Those values are low according to the Resende (2002) classification and indicate the need for improvement of the experimental design. Mendes (2019) also reported low values of accuracy for Brazilian native timber species. The accuracy improvement is directly related to the increase in the number of replications and better experimental establishment, aiming to have homogeneous blocks displayed in the whole experimental area. Thus, experimental design should be pointed out as an important factor when Brazilian native timber species are involved, in order to improve accuracy values in genetic breeding experiments.

The coefficient of genotypic variation between progenies ( $\mathrm{CV}_{p g} \%$ ) of all traits evaluated were low, ranging from $1.65 \%$ to $10 \%$, respectively, for the number of stems and $\mathrm{DBH}$. Thus, the DBH trait was shown to be the most appropriate for selection. The residual variation coefficients $\left(\mathrm{CV}_{e} \%\right)$ varied from $1.99 \%$ to $3.18 \%$, in general obtaining values lower than the $\mathrm{CV}_{p g} \%$, except in relation to the number of stems and survival. The coefficient of relative variation $\left(\mathrm{CV}_{r}\right)$ informs the existence of variation between progenies compared to residual variation when it has a value greater than 1. In this regard, the traits DBH (4.67), tree shape (2.94), and branch thickness (4.41) presented values of great variation between progenies, while number of stems $(0.83)$ and survival $(0.57)$ showed less variation between progenies. This indicates that the variation observed for these traits is almost completely random.

The general means of the traits were as follows: $\mathrm{DBH}, 7.83 \mathrm{~cm}$; number of stems, Grade 1.14; tree shape, Grade 2.25; branch thickness, Grade 1.92; and survival, 74\%. A similar value for the DBH trait was found for Schizolobium parahyba, which presented a value equal to 10.07 $\mathrm{cm}$ at three years of age (Ohashi et al., 2010). In the evaluation of genetic variation in populations of the native Brazilian species Balfourodendron riedelianum for ex situ conservation, a mean DBH of $7.88 \mathrm{~cm}$ was observed at nine years of age (Siqueira et al., 2000). Similarly, in a provenance test of Araucaria angustifolia, a mean DBH of $9.96 \mathrm{~cm}$ was observed at the same age (Sebbenn et al., 2004). Despite the distinct characteristics of the experiments, these results, compared to the overall mean growth in DBH of $Z$. tuberculosa $(7.83 \mathrm{~cm})$, indicates a potential rapid growth of woody species at the age of three.

\section{Family selection}

The ranking of families was done by their predicted genetic values and estimated gains. In total, 30 families were counted in the progeny test, of which fourteen were selected for the formation of indoor clonal recombination orchards as they displayed positive values for genetic gains. There was a great difference in genetic gains, i.e., a difference of almost fivefold, between the first ranked family (No. 17, 32.34\%) and the $10^{\text {th }}$ ranked family (No. 9, 6.29\%) (Table 2). Therefore, it is recommended that the selection of potential progenitors be done from top-ranked families with positive genetic gains. 
Table 2. Ranking of the 10 best selected families of $Z$. tuberculosa by their genetic values $(u+a)$ and gain with selection in relation to the general mean of the test.

\begin{tabular}{cccc}
\hline Rank & Family & $\mathbf{u}+\mathbf{a}$ & Gain (\%) \\
\hline 1 & 17 & 10.37 & $32.34 \%$ \\
2 & 20 & 9.81 & $25.19 \%$ \\
3 & 29 & 9.71 & $23.84 \%$ \\
4 & 18 & 9.47 & $20.81 \%$ \\
5 & 25 & 9.34 & $19.19 \%$ \\
6 & 19 & 9.03 & $15.14 \%$ \\
7 & 26 & 8.74 & $11.49 \%$ \\
8 & 30 & 8.49 & $8.27 \%$ \\
9 & 16 & 8.46 & $7.93 \%$ \\
10 & 9 & 8.33 & $6.29 \%$ \\
\hline
\end{tabular}

This ranking indicates that the selected mother trees from which seeds were collected to form the test families would make it possible to obtain considerable genetic gains in the generation of progenies. For this, it would be necessary to return to each municipality to collect grafts from the selected matrices. Because of the difficulty in reaching the tree tops or the high cost of returning to their location to perform this work, it was preferable to use selected individuals in the test as potential progenitors. In addition, it was also possible to send individuals to a program for cloning potential trees.

Many native Brazilian species with potential use in silviculture still need to be studied in terms of genetic gains with family selection. The lack of information in this regard makes it difficult to verify the genetic potential of many Brazilian native timber species in forest breeding programs. Thus, research initiatives in the area of genetic breeding, aiming to guarantee the development of genetically superior Brazilian native individuals, are recommended.

\section{Selection of potential progenitors}

Selection of potential progenitors with a rectilinear shape and an ideal stem was done considering the genetic value $(u+a)$ predicted in relation to the DBH trait. The ranking of individuals by their genetic values is important for the selection of materials destined for hybridization orchards and for use in the seminal propagation of elite genotypes (Mendes, 2019). In the selection of potential progenitors, individuals with the shape and number of stems evaluated with grade 1 and belonging to families with positive genetic values were selected (Table 3). Gains from potential selected progenitors showed estimates considered to be highly capable of transmitting their genetic value to the descendants; these individuals were characterized as being of great importance in the formation of the hybridization orchard.

Table 3. Ranking of potential genitors of $Z$. tuberculosa by their diameter at breast height $(\mathrm{DBH}, \mathrm{cm})$ genetic values $(u+a)$ and predicted genetic gains with selection in relation to the general mean of the test.

\begin{tabular}{cccccc}
\hline Rank & Block & Family & Tree & $\mathbf{u + a}$ & Gain (\%) \\
\hline 1 & 6 & 17 & 167 & 10.50 & $33.98 \%$ \\
2 & 6 & 19 & 169 & 10.15 & $29.46 \%$ \\
3 & 3 & 20 & 79 & 9.80 & $25.04 \%$ \\
4 & 8 & 18 & 228 & 9.61 & $22.55 \%$ \\
5 & 6 & 25 & 175 & 9.48 & $21.00 \%$ \\
6 & 3 & 28 & 86 & 9.29 & $18.53 \%$ \\
7 & 4 & 29 & 117 & 9.20 & $17.33 \%$ \\
8 & 2 & 4 & 34 & 9.01 & $14.98 \%$ \\
9 & 1 & 9 & 9 & 8.97 & $14.46 \%$ \\
10 & 1 & 11 & 11 & 8.44 & $7.72 \%$ \\
\hline
\end{tabular}




\section{Selection of potential clones}

The selection of potential clones considers the genotypic value of the individuals evaluated in the test. The gain in the genotypic value is the result of the sum of the genetic and non-genetic effects of the population (Osorio et al., 2001). This value is measured using methods of quantitative genetics that allow starting from the measured phenotypic values to separate the part that corresponds to the genotypic value, i.e., the part that disregards the influence of the environment. Thus, by obtaining the genotypic gain, it is possible to assess the genetic superiority of each individual and make decisions about which one to select for cloning in the breeding program. The ranking of potential clones revealed individuals with high genotypic value and gains greater than $41.09 \%$ (Table 4). These are important for cloning and establishing clonal tests via vegetative propagation (Osorio et al., 2001).

Table 4. Ranking of potential clones of $Z$. tuberculosa by their genotypic values $(u+g)$ and predicted gains for diameter at breast height $(\mathrm{DBH}, \mathrm{cm})$.

\begin{tabular}{cccccc}
\hline Rank & Block & Family & Tree & $\mathbf{u + g}$ & Gain (\%) \\
\hline 1 & 6 & 17 & 167 & 13.80 & $75.99 \%$ \\
2 & 6 & 19 & 169 & 13.30 & $69.69 \%$ \\
3 & 5 & 17 & 136 & 13.00 & $65.81 \%$ \\
4 & 4 & 17 & 105 & 12.71 & $62.19 \%$ \\
5 & 1 & 17 & 17 & 12.51 & $59.58 \%$ \\
6 & 3 & 20 & 79 & 12.40 & $58.14 \%$ \\
7 & 6 & 20 & 170 & 12.15 & $55.03 \%$ \\
8 & 8 & 18 & 228 & 11.71 & $49.36 \%$ \\
9 & 6 & 25 & 175 & 11.55 & $47.39 \%$ \\
10 & 7 & 17 & 198 & 11.06 & $41.09 \%$ \\
\hline
\end{tabular}

\section{Genetic progress}

An open cross among the top ten potential progenitors was simulated in order to calculate the future breeding population yield. The simulation addressed seeds collected from each top-ranked potential progenitor, enabling the estimation of genetic gains by planting these seeds (Table 5). Seeds collected from tree 167 (potential progenitor selected and opencrossed with nine other superior genotypes in clonal recombination orchards) were found to have the potential to generate a population with a mean yield of $9.97 \mathrm{~cm}$ in $\mathrm{DBH}$, a $27.24 \%$ gain in relation to the base population (general mean of $7.83 \mathrm{~cm}$ for $\mathrm{DBH}$ ).

Table 5. Ranking of Z. tuberculosa selected potential progenitors and estimated diameter at breast height $(\mathrm{DBH}, \mathrm{cm})$ mean (E.D.M.) of seeds after open cross simulation in each one of these potential genitors.

\begin{tabular}{ccccccc}
\hline Rank & Block & Family & Tree & $\mathbf{u}+\mathbf{a}$ & E.D.M. & G.G.S. \\
\hline 1 & 6 & 17 & 167 & 10.50 & 9.97 & $27.24 \%$ \\
2 & 6 & 19 & 169 & 10.15 & 9.80 & $24.98 \%$ \\
3 & 3 & 20 & 79 & 9.80 & 9.62 & $22.77 \%$ \\
4 & 8 & 18 & 228 & 9.61 & 9.53 & $21.53 \%$ \\
5 & 6 & 25 & 175 & 9.48 & 9.47 & $20.75 \%$ \\
6 & 3 & 28 & 86 & 9.29 & 9.37 & $19.52 \%$ \\
7 & 4 & 29 & 117 & 9.20 & 9.32 & $18.92 \%$ \\
8 & 2 & 4 & 34 & 9.01 & 9.23 & $17.74 \%$ \\
9 & 1 & 9 & 9 & 8.97 & 9.21 & $17.48 \%$ \\
10 & 1 & 11 & 11 & 8.44 & 8.95 & $14.11 \%$ \\
\hline
\end{tabular}

E.D.M.: Estimated DBH (cm) mean of trees from the seeds collected in each selected tree; G.G.S.: Genetic gain with the seeds collected in each selected tree; $u+a$ : genetic value. 
In general, future plantations generated from seeds of each potential progenitor that passed through open crossings among the selected genotypes (Figure 1, Selected_pop) could provide genetic gains ranging from $14.11 \%$ to $27.24 \%$ in relation to the original breeding population (Figure 1, Base_pop). The mean genetic progress for DBH of a future population composed of all seeds from selected and open-crossed potential genitors was $1.55 \mathrm{~cm}$ (breeding population mean offset), which represents a genetic gain of $20 \%$ in relation to the original population of $Z$. tuberculosa (Figure 1).

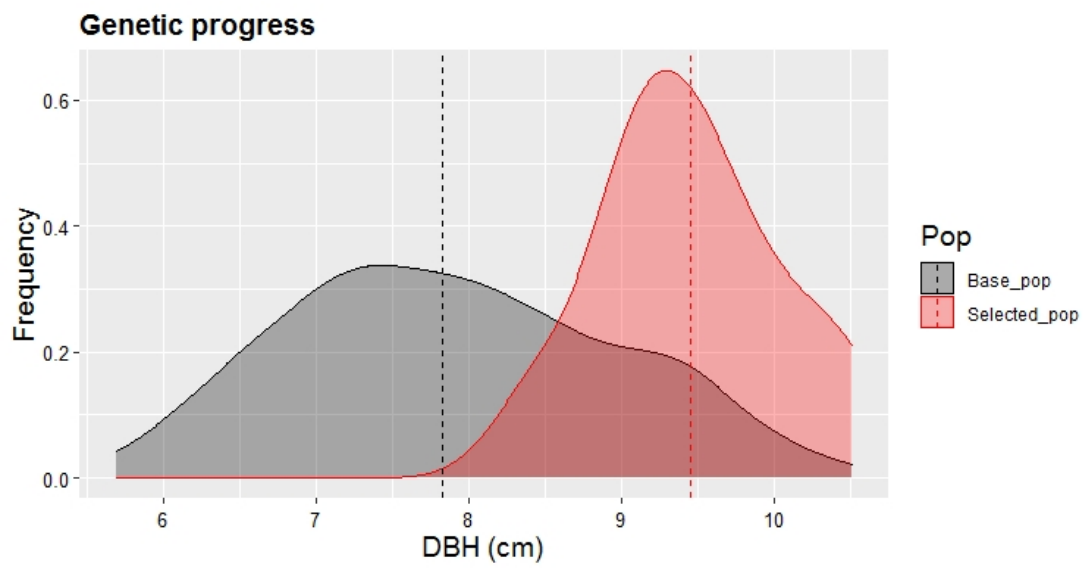

Figure 1. Z. tuberculosa breeding population mean offset for diameter at breast height (DBH, $\mathrm{cm})$. Base_pop represents the breeding population of the test and Selected_pop represents the population composed by the ten potential progenitors selected according to genetic values. Dashed vertical lines represents the genetic mean of each population.

\section{Grafting}

The rate of grafting success for $Z$. tuberculosa ranged from $20 \%$ to $80 \%$ among the 10 selected genotypes; the overall mean grafting success rate was $51 \%$ (Table 6 ). The genotypes belonging to families 4 and 17 showed excellent potential for vegetative propagation, with a take rate of $80 \%$. Therefore, these families can be indicated for cloning via grafting, aiming to develop an early flowering induction and artificial pollination program.

Table 6. Grafting characterization for each $Z$. tuberculosa genotype (family), mean rootstock diameter (MRD, mm), mean graft diameter (MGD, mm), grafting success rate (GSR, \%) and degree of kinship (Kns) between graft and rootstock.

\begin{tabular}{ccccc}
\hline Family & MRD & MGD & GSR & Kns \\
\hline 4 & 18.12 & 15.06 & $80 \%$ & $25 \%$ \\
17 & 15.56 & 11.66 & $80 \%$ & $0 \%$ \\
19 & 17.79 & 12.58 & $70 \%$ & $25 \%$ \\
18 & 16.38 & 11.55 & $60 \%$ & $25 \%$ \\
25 & 17.64 & 13.39 & $50 \%$ & $25 \%$ \\
29 & 14.83 & 13.11 & $50 \%$ & $0 \%$ \\
20 & 11.77 & 11.61 & $40 \%$ & $25 \%$ \\
9 & 14.91 & 13.62 & $30 \%$ & $25 \%$ \\
28 & 16.14 & 11.88 & $30 \%$ & $0 \%$ \\
11 & 14.33 & 13.36 & $20 \%$ & $25 \%$ \\
\hline
\end{tabular}

The statistical correlation analysis indicated the existence of a relationship between the increase in grafting success rate and the mean size of the rootstocks, which presented a mean value of $1.5 \mathrm{~cm}$ (Figure 2). This size is found in the literature as suitable for grafting $(1-1.5 \mathrm{~cm})$ (Lee et al., 2010), confirming the information for the efficiency of the technique. The 
correlation between grafting success rate and the mean graft diameter variable showed a result that indicates no relationship (0.06). This result is associated with the standardization of graft diameters performed on the day of their collection in the field. Additionally, other factors also influence the success of grafting, such as physiological vigor of rootstocks, phytosanitary status of the seedlings, genotypes collected, experience of the grafters, and relationship between the graft and rootstock.

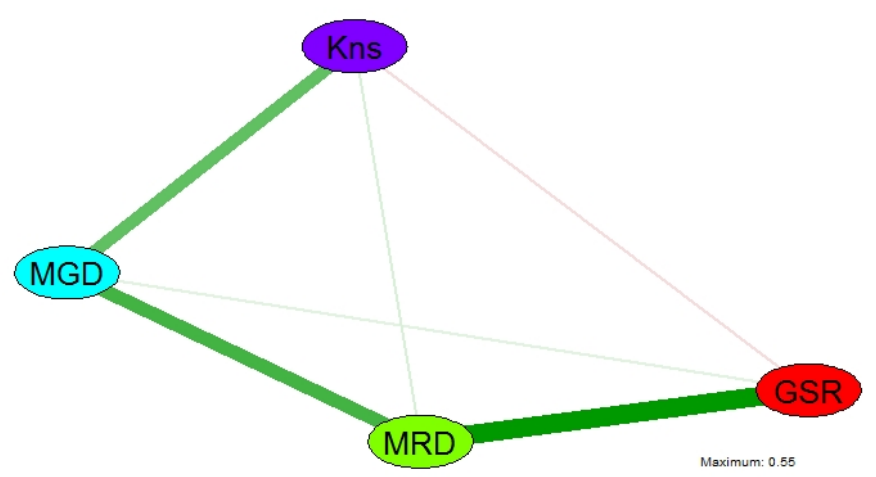

Figure 2. Correlation network among mean rootstock diameter (MRD, mm), mean graft diameter (MGD, $\mathrm{mm}$ ), grafting success rate (GSR, \%) and degree of kinship (Kns) between graft and rootstock. The thicker the line connecting the circles, the greater the magnitude of correlations. All correlation values were positive, except for the correlation between GSR and Kns.

In the present study, kinship between graft and rootstock showed a low correlation (0.07) with the grafting success rate when evaluated 60 days after grafting. However, symptoms of genetic incompatibility of the graft and rootstock can occur at the beginning or even one to two years after the graft was made, depending on the species (Mendes et al., 2020). Studies on grafting techniques that correlate the grafting success rate with the size of the mean roostock and graft diameter are scarce. Therefore, it is expected that this study will contribute to new research that aims to analyze the relationship between characteristics associated with grafts to the success rate of grafting.

The genetic selection program of the native Brazilian species Z. tuberculosa proved to be effective in recommending superior genetic materials for silviculture and structuring an indoor clonal orchard. The potentially selected clones can be made available to rural producers interested in producing high-quality wood, and the potential progenitors are ideal for forming an indoor recombination orchard, since they presented high genetic gains and high viability after cloning via top cleft grafting. Thus, it is expected that through consecutive controlled crosses, future generations of trees will have improved phenotypic characteristics of DBH and stem, as evidenced by the estimate of genetic progress. In this sense, the information contained in this study may promote the introduction of this native Brazilian species into plantations of rural producers and the development of the forestry sector through the production of new high-quality wood products.

\section{CONCLUSIONS}

Statistical genetic analysis of genotypes of the native Brazilian species Z. tuberculosa indicated the existence of progenies with genetic merit, presenting individuals with potential for gain upon appropriate selection as potential clones, genitors, and matrices. Estimation of genetic parameters also indicated success in testing progenies and favorable conditions for breeding programs.

A study of genetic progression of the breeding population showed genetic advancement and gain in the silvicultural trait $\mathrm{DBH}$, favoring the availability of superior genetic materials for silviculture. In addition, the simulation of open pollination in an indoor orchard revealed a 
positive result, in that the new population is estimated to have a higher mean DBH compared to the original population of the test. Thus, the breeding adopted will favor an increase in gains for the species.

The grafting of native Brazilian species Z. tuberculosa is feasible by means of the top wedge technique, with a success rate of $51 \%$, resulting in the possibility of accelerating genetic breeding cycles for this species. The genotypes belonging to families 4 and 17 stand out as having excellent potential in this regard, with a take rate of $80 \%$. In addition, among the various factors that influence the success of grafting, the diameter of the rootstock is an essential factor to be considered in the breeding programs of $Z$. tuberculosa.

\section{ACKNOWLEDGMENTS}

The authors thank Conselho Nacional de Desenvolvimento Científico e Tecnológico (CNPQ), No: 433173/2018-1 for the financial support, Universidade Federal do Sul da Bahia (UFSB) and Symbiosis Investimentos e Participações S. A. for their support.

\section{REFERENCES}

Beech, E., Rivers, M., Oldfield, S., \& Smith, P. P. (2017). Global Tree Search: the first complete global database of tree species and country distributions. Journal of Sustainable Forestry, 36(5), 454-589. http://dx.doi.org/10.1080/10549811.2017.1310049.

Bhering L. L. (2017). Rbio: a tool for biometric and statistical analysis using the R platform Crop Breed. Crop Breeding and Applied Biotechnology, 17(2), 187-190. http://dx.doi.org/10.1590/1984-7033201 7v17n2s29.

Canuto, D. S. O., Silva, A. M., Freitas, M. L. M., Sebbenn, A. M., \& Moraes, M. L. T. (2017). Genetic Variability in Myracrodruon urundeuva (Allemão) Engl. Progeny Tests. Journal of Forestry, 7(1), 1-10. http://dx.doi.org/10.4236/ojf.2017.71001.

Carvalho, H. F., Silva, F. L., Resende, M. D. V., \& Bhering, L. L. (2019). Selection and genetic parameters for interpopulation hybrids between kouilou and robusta coffee. Bragantia, 78(1), 52-59. http://dx.doi.org/10.1590/1678-4499.2018124.

Costa, R. B., Resende, M. D. V., Contini, A. Z., Rego, F. L. H., Roa, R. A. R., \& Martins, W. J. (2005). Avaliação genética de indivíduos de erva-mate (Ilex paraguariensis St. Hill.) na região de Caarapó, MS, pelo procedimento REML/BLUP. Ciência Florestal, 15(4), 371-376. http://dx.doi.org/10.5902/198050981874.

Dickinson, G. R., Wallace, H. M., \& Lee, D. J. (2010). Controlled pollination methods for creating Corymbia hybrids. Silvae Genetica, 59(5), 233-241. http://dx.doi.org/10.1515/sg-2010-0028.

Duarte, R. I., Silva, F. A. L. S., Schultz, J., Silva, J. Z., \& Reis, M. S. (2012). Características de desenvolvimento inicial em teste de progênie de uma população de araucária na flona de três barras-sc. Biodiversidade Brasileira, 2(2), 114-123.

Food and Agriculture Organization of the United Nations - FAO. (2020). Global forest resources assessment 2020. Rome: FAO. http://dx.doi.org/10.4060/ca8753en.

Freitas, M. L. M., Aukar, A. P. A., Sebbenn, A. M., Moraes, M. L. T., \& Lemos, E. G. M. (2006). Variação genética em progênies de Myracrodruon urundeuva FF \& MF Allemão em três sistemas de cultivo. Revista Árvore, 30(3), 319-329. http://dx.doi.org/10.1590/S0100-67622006000300001.

Freitas, M. L. M., Sebbenn, A. M., Zanatto, A. C. S., \& Moraes, E. (2007). Pomar de sementes por mudas a partir da seleção dentro em teste de progênies de Myracrodruon urundeuva fr. all. Revista do Instituto Florestal, 19(2), 65-72.

Gallo, R., Pantuza, I. B., Santos, G. A., Resende, M. D. V., Xavier, A., Simiqueli, G. F., Baldin, T., Santos, O. P., \& Valente, B. M. R. T. (2018). Growth and wood quality traits in the genetic selection of potential Eucalyptus dunnii Maiden clones for pulp production. Industrial Crops and Products, 123, 434-441. http://dx.doi.org/10.1016/j.indcrop.2018.07.016.

Gianotti, E., Timoni, J. L., Mariano, G., Coelho, L. C. C., Fontes, M. A., \& Kageyama, P. Y. (1982). Variação genética entre procedências e progênies de Araucaria angustifolia (Bert.) O. Ktze. Silvicultura em São Paulo, 16(2), 970-975.

Guerra, C. R. S. B., Moraes, M. L. T., Silva, C. L. S. P., Canuto, D. S. O., Andrade, J.A.C., Freitas, M. L. M., \& Sebbenn, A.M. (2009). Estratégias de seleção dentro de progênies em duas populações de Myracrodruon urundeuva Fr. All. Scientia Forestalis, 37(81), 79-87. 
Kubota, T. Y. K., Moraes, M. A., Silva, E. C. B., Pupin, S., Aguiar, A. V., Moraes, M. L. T., Freitas, M. L. M., Sato, A. S., Machado, J. A. R., \& Sebbenn, A. M. (2015). Variabilidade genética para caracteres silviculturais em progênies de polinização aberta de Balfourodendron riedelianum (Engler). Scientia Forestalis, 43(106), 407-415.

Lee, J., Kubota, C., Tsao, S. J., Bie, Z., Echevarria, P. H., Morra, L., \& Oda, M. (2010). Current status of vegetable grafting: diffusion, grafting techniques, automation. Scientia Horticulturae, 127(8), 93-105. http://dx.doi.org/10.1016/j.scienta.2010.08.003.

Mendes, G. G. C. (2019). Genetic analysis, grafting and orchard formation of crosses in pots with tree species native to Brazil. (Dissertação de mestrado). Universidade Federal de Viçosa, Viçosa.

Mendes, G., Santos, G., Resende, M., Martins, S., Souza, G., Nunes, A., \& Martins, T. (2020). Flowering acceleration in native Brazilian tree species for genetic conservation and breeding. Annals of Forest Research, 63(1), 39-52. http://dx.doi.org/10.15287/afr.2019.1751.

Mendonça, G. C., Chichorro, J. F., Mendonça, A. R., \& Guimarães, L. A. O. P. (2017). Avaliação silvicultural de dez espécies nativas da Mata Atlântica. Ciência Florestal, 27(1), 277-290. http://dx.doi.org/10.5902/1980509826466.

Moraes, M.A., Filho, W. V. V., Resende, M. D. V., Silva, A. M., Manoel, R. O., Freitas, M. L. M., Moraes, M. L. T., \& Sebbenn, M. L. M. (2012). Produtividade, estabilidade e adaptabilidade em progênies de Myracrodruon urundeuva F.F. \& M.F. Allemão - Anacardiaceae. Scientia Forestalis, 40(93), 69-76.

Nicodemo, M. L. F., Muller, M. D., Porfírio-da-Silva, V., Carpanezzi, A. A., Pezzopane, J. R. M., \& Barioni Júnior, W. (2016). Growth of native trees in two agroforestry systems. Revista Árvore, 40(4), 639-648. http://dx.doi.org/10.1590/0100-67622016000400007.

Ohashi, S. T., Yared, J. A. G., \& Farias Neto, J. T. (2010). Variabilidade entre procedências de paricá Schizolobium parahyba var. amazonicum (Huber ex Ducke) plantadas no município de Colares Pará. Acta Amazonica, 40(1), 81-88. http://dx.doi.org/10.1590/S0044-59672010000100011.

Osorio, L. F., White, T. L., \& Huber, D. A. (2001). Age trends of heritabilities and genotype-byenvironment interactions for growth traits and wood density from clonal trials of Eucalyptus grandis Hill ex Maiden. Silvae Genetica, 50(1), 30-37.

Otsubo, H. C. B., Moraes, M. L. T., Moraes, M. A., José Neto, M., Freitas, M. L. M., Costa, R. B., Resende, M. D. V., \& Sebbenn, A. M. (2015). Variação genética para caracteres silviculturais em três espécies arbóreas da região do bolsão sul-mato-grossense. Cerne, 21(4), 535-544. http://dx.doi.org/10.1590/01047760201521041317.

R Development Core Team (2020). R: a language and environment for statistical computing. Vienna: $\mathrm{R}$ Foundation for Statistical Computing. Retrieved in 2020, November 16, from http://www.Rproject.org/

Resende, M. D. V. (2002). Genética biométrica e estatística no melhoramento de plantas perenes (975 p.). Colombo: Embrapa Florestas.

Resende, M. D. V. (2016). Software Selegen-REML/BLUP: a useful tool for plant breeding. Crop Breeding and Applied Biotechnology, 16(4), 330-339. http://dx.doi.org/10.1590/1984-70332016v16n4a49.

Sarmento, P. A., Ataíde, T. R., Barbosa, A. P. F., Araújo-Júnior, J. X., Lúcio, I. M., \& Bastos, M. L. (2014). Evaluation of the extract of Zeyheria tuberculosa with a view to products for wound healing. Revista Latino-Americana de Enfermagem, 22(1), 165-172. PMid:24553718. http://dx.doi.org/10.1590/01041169.3143.2385.

Sebbenn, A. M., Freitas, M. L. M., Zanatto, A. C. S., \& Moraes, E. (2009). Seleção dentro de progênies de polinização aberta de Cariniana legalis mart. o. ktze (lecythidaceae), visando à produção de sementes para recuperação ambiental. Revista do Instituto Florestal, 21(1), 27-37.

Sebbenn, A. M., Kageyama, P. Y., \& Zanatto, A. C. S. (2002). Estimativas de ganhos genéticos na seleção em populações de Cariniana legalis (Mart.) O. Ktze, incorporando informações do sistema misto de reprodução. Revista do Instituto Florestal, 14(1), 65-77.

Sebbenn, A. M., Pontinha, A. A. S., Freitas, S. A., \& Freitas, J. A. (2004). Variação genética em cinco procedências de Araucaria angustifolia (bert.) o. ktze. no sul do estado de são paulo. Revista do Instituto Florestal, 16(2), 91-99.

Sebbenn, A. M., Siqueira, A. C. M. F., Vencovsky, R., \& Machado, J. A. R. (1999). Interação genótipo x ambiente na conservação ex situ de Peltophorum dubium, em duas regiões do estado de São Paulo. Revista do Instituto Florestal, 11(1), 75-89.

Senna, S. N., Freitas, M. L. M., Zanatto, A. C. S., Morais, E., Zanata, M., Moraes, M. L. T., \& Sebbenn, A. M. (2012). Variação e parâmetros genéticos em teste de progênies de polinização livre de Peltophorum dubium (Sprengel) taubert em Luiz Antonio -SP. Scientia Forestalis, 40(95), 345-352. 
Siqueira, A. C. M. F., Sebbenn, A. M., Ettori, L. C., \& Nogueira, J. C. B. (2000). Variação genética entre e dentro de populações de Balfourodendron riedelianum (Engler) Engler para conservação ex situ. Revista do Instituto Florestal, 12(2), 89-103.

Tian, X., Sohgen, B., Kim, J. B., Ohrel, S., \& Cole, J. (2016). Global climate change impacts on forests and markets. Environmental Research Letters, 11(3), 1-10. http://dx.doi.org/10.1088/17489326/11/3/035011.

Zaruma, D. U. G., Canuto, D. S. O., Pupin, S., Cambuin, J., Silva, A. M. S., Mori, E. S., Sebbenn, A. M., \& Moraes, M. L. T. (2015). Variabilidade genética em procedências e progênies de Dipteryx alata vogel para fins de conservação genética e produção de sementes. Scientia Forestalis, 43(107), 609-615.

Authors' contributions: MSPBG: Investigation, Data curation, Formal analysis, Visualization, Writing - original draft; ACPN: Conceptualization, Funding acquisition, Investigation, Project administration, Resources, Supervision, Visualization, Writing - review \& editing; APS and FGM: Investigation, Data curation, Writing - review \& editing. 